откладывается на неопределенный срок, либо не реализуется вообще.

Отметим, что медицинские технологии дали постиндустриальному субъекту возможность значительно продлить срок своей молодости (как во внешнем облике, так и в психологическом самоощущении). Одним из достижений постиндустриального общества является то, что молодость теперь не зависит от биологического возраста: «Сама для себя из молодости я еще не вышла и, полагаю, не выйду еще некоторое время. Слишком уж привлекателен растиражированный и уже устоявшийся образ молодежности [...]. Безусловно, тезис о разрушении «ассоциации между молодежностью и возрастом» ныне вполне справедлив»[8, с. 457-458]. Ощущая себя молодой и свободной, современная женщина при желании может осуществить любую репродуктивную стратегию, в том числе и монородительскую (стратегию «матери-одиночки»), особенно при наличии достаточного уровня материальной обеспеченности.

Тот факт, что на место ценности производства в постиндустриальном обществе приходит ценность потребления, не подлежит сомнению. Это столь же верно, как и то, что на смену советскому аскетизму приходит постсоветский гедонизм. Отмеченный ценностный сдвиг приводит в итоге к тому, что индивид сам становится ребенком, пользующимся плодами чужого труда и не нуждающимся ни в собственных детях, ни в интимной близости как таковой. Помимо движения «child free» в ряде стран (в том числе России) постепенно развивается движение, представители которого осуществляют полный отказ от сексуальной жизни.

В заключении следует сделать вывод о том, что нормативно-ценностные установки человека постиндустриального общества постепенно приводят к тому, что институт традиционной семьи отмирает. На смену ему приходят репродуктивные стратегии, в качестве идеала предполагающие партнерскую семью, свободные отношения (сожительство) или монородительскую семью. При этом, обладая значительной свободой, постиндустриальный индивид готов полностью отказаться от сексуальной активности и рождения детей в пользу «жизни для себя».

\section{Литература:}

1. См. Вирилио П. Информационная бомба. Стратегия обмана / П. Вирилио/ - М.: ИТДГК «Гнозис», Фонд «Прагматика культуры», 2002. $192 \mathrm{c}$.

2. Жидкова Е. Практики разрешения семейных конфликтов в 1950-60-е годы: обращения граждан в общественные организации и партийные ячейки/ Е. Жидкова // Советская социальная политика: сцены и действующие лица, 1940-1985. - М.: ООО «Вариант», ЦСПГИ, 2008. С. 283.

3. Забаев И. «Своя жизнь», образование, деторождение: мотивация репродуктивного поведения в современной России/ И. Забаев// Вестник общественного мнения. № 3 (105). 2010. С. 87-97. C. 96.

4. Омельченко Е.Л. Начало молодежной эры или смерть молодежной культуры? «Молодость» в публичном пространстве современности/ Е.Л. Омельченко // Журнал исследований социальной политики. Т. 4. № 2. 2006. С. 152.

5. Гундаров И.Духовное неблагополучие и демографическая катастрофа/ И. Гундаров. Электронный ресурс. Режим доступа: http://gorizontsobytij.ucoz.ru/publ/dukhovnoe_neblag opoluchie_i_demograficheskaja_katastrofa/2-1-0-127

6. Яницкий М.С. Система ценностных ориентаций «поколения Z»: социальные, культурные и демографические детерминанты/ М.С. Яницкий, А.В. Серый, О.А. Браун, Ю.В. Пелех, О.В. Маслова, М.В. Сокольская, Р.Д. Санджаева, А.Р. Монсонова, С.Б. Дагбаева, Ю.Ю. Неяскина, Р.В. Кадыров, Т.В. Капустина // Сибирский психологический журнал. 2019. № 72. С. 46-67. C.61.

7. Маркс К. Немецкая идеология/ К. Маркс, Ф. Энгельс-М.: Партиздат, 1934. С. 19.

8. Бредникова О. Там же. Бредникова О. «Старородящая» молодая мать (институциональные игры с категориями возраста)// Новый быт современной России: гендерные исследования повседневности: коллективная монография. - СПб.: Издательство Европейского университета в Санкт-Петербурге, 2009. C. 456-472. C. 457-458.

\title{
SOCIAL KNOWLEDGE: THE AMBIVALENCE OF DEVELOPMENT MODELS
}

\author{
Mamedov Agamali Kulamovich \\ doctor of Sociological Sciences, professor \\ Moscow State University named after M.V. Lomonosov \\ Moscow, Russia \\ DOI: $10.31618 /$ nas.2413-5291.2020.1.58.275
}

\section{Annotation}

The article declares the position of dissensus and consensus as basic models for the development of social sciences. The demarcation of natural sciences and social sciences is carried out. Attempts are being made to identify the features of "acceptance" by the scientific community. The article analyzes L. Laudan's concept of consensus in modern social knowledge.

Keywords: dissensus, consensus, convention, epistemology, agreement, foundation, scientific communication. 
The global crisis, into which the world is rapidly "rolling", once again raises the question of the effectiveness of social cognition, the soundness of conclusions and the reality of forecasts. The fragmentation of the social sciences, their unfounded claim to methodological universality and totality, inevitably actualizes the question of the nature of social cognition, the criteria of scientific character, optics and the generally accepted scale of measurement. Unlike natural science, where the convention for the choice of units of measurement is in most cases trivial and is often carried out by default, in social cognition, the adoption of such conventions becomes a problem for the scientific community to accept new knowledge, acculturation of knowledge, the foundation of its conclusions, as well as translation of qualitative properties and characteristics into quantitative parameters. With all the awareness of that huge step in the development of the social sciences, accomplished by the positivists, in particular, O. Comte and G. Spencer, we note that they themselves, criticizing, often unfairly and superficially, the preceding social science, did not depart far from them in terms of claims on a universal methodology. An attempt to incorporate social knowledge into natural science, replacing metaphysical (in the literal sense) concepts with positivism, and very naive, led not only to the denial of the great heritage of the classics, but also to ignoring the subject of knowledge, his attitudes and values. Subsequently, this problem had to be solved in neoKantianism, first of all, by Wilhelm Windelbandt. So, in specific sociological studies, qualitative characteristics (for example, prestige, social belonging, opinion and needs) do not have uniform measurement standards accepted by the entire community, because the content of these concepts is very wide and heterogeneous. And the inherent characteristics are very personal in nature. They (the specified parameters) are constructed in accordance with the nature of the object under study and according to the hypothesis of the research, and, consequently, the personal attitude of the scientist. The practical possibilities of measurements essentially depend on the ability of the researcher to find and substantiate (not only for himself) a reliable measurement procedure, to achieve its acceptance in the nearest expert community [7]. So, in particular, the most important procedure for constructing a measurement scale and its founding includes involuntarily conventional points that require a qualitative classification of objects (within the framework of the research concept), highlighted in the qualitative analysis of properties, identifying empirical indicators of object properties that can be ranked, etc. Even this method specific sociological research as content analysis also needs to translate qualitative information "into the language of counting", because it must be accepted and verified. The conventional aspects here also increase significantly in connection with such an important factor as the ideological principles and attitudes that underlie the selection and isolation of the objects of analysis. At the same time, both the "costs" of unreasonable and hasty agreements and the corresponding methods of their prevention and withdrawal are especially evident here. In particular, methods of checking the measurement procedure for reliability have been developed and are being improved, which is determined by three criteria: validity, stability and accuracy of the scale; for the measurement procedure, the principles of utility and pragmatics are formulated (the measurement system must certainly correspond to the object of measurement, the standard and units of measurement must accurately record the properties and characteristics of the object determined by the research program itself). These methods are implemented in a specific study based on empirical material, only in this way is the approbation of the accepted conventions possible and widely used here. In general, it should be noted that the uncertainty and ambiguity of the introduced conventions is largely due to the lack of a developed and acculturated conceptual apparatus for the transition from theoretical constructs to empirical material [8].

The specificity of social and humanitarian cognition, which is difficult to quantify, the introduction of rigorous mathematical methods, as well as experimental verification, are especially manifested in attempts at the now fashionable computer modeling. Interesting in this regard are the developments of scientists in the field of engineering linguistics and machine translation, whose accumulated rich material is very important for understanding the nature of humanitarian knowledge, the features of its methods, including conventions, in particular in linguistic sciences. The experience of linguistic research revealed that one of the main (if not the most important) difficulties in the work of scientists was the absence or too narrow field of a well-grounded and accepted methodological apparatus in the scientific community that made it possible to correctly apply fundamental theories or even paradigms to a specific linguistic material in applied research. The impossibility of checking the correspondence of the theory to the real state of affairs led to the fact that linguists were forced to rely on several, often mutually exclusive hypotheses, violating the logic and methodology of the study. It is obvious that in this case the problem of convention arises, first of all, as a problem of choosing a hypothesis (theory) and the concept underlying it; the criterion for such a choice is, at best, formal truth. Thus, it is obvious that scientific search, in the social sciences, is impossible without the conventional choice of a hypothesis (operationally interpreted concepts, units and methods of measurement, that is, the entire optics of research) as a "working", since there is no conceptual and operational apparatus of application theories to empirical concrete material and it is impossible to directly (experimentally) test the conformity of the hypothesis to the state of affairs [6].

A similar situation takes place in sociological research, where the a priori accepted "one-thread" (B. Khazanov's term) theoretical propositions often generate very unusual conclusions. The marginal intelligible constructs generated in the minds suddenly gave rise to global and all-encompassing conclusions. Hence, a methodological requirement arises, which is 
more and more realized by humanities researchers: a constant critical analysis of the foundations of hypotheses, the testing of explicit or implicit conventions included in them, a conscious overcoming of the tendency to elevate the content of such agreements to the rank of objective laws is necessary. Consensus in cognitive activity, reflecting its communicative nature, can receive the status of scientific concepts, hypotheses, methods, in essence, only with their collective acceptance. As the British researcher S. Toulmin noted, an individual initiative can lead to the discovery of new truths, the development of new concepts is a purely collective matter. The new proposal will be worthy of experimentation and early development once it is collectively considered worthy of attention. The statement of these facts necessarily actualizes the problem of the adoption and functioning of conventions in conditions of professional consent (consensus) or disagreement (dissensus). Consensus is understood as the degree of consolidation, consistency in the scientific community regarding cognitive standards, ontological prerequisites, and the system of value orientations in general. Consent (disagreement, mismatch) is investigated as a kind of communication mechanism in a variety of functions, one of which is to be the logical basis for the development of scientific knowledge, which is also important for understanding the nature of social science. In particular, the methodological consensus is the adoption of conventions on cognitive standards for the choice of the central, priority problem, the premises of its research, acceptable theoretical approaches, methods and techniques, and useful techniques. By itself, a high degree of consensus does not guarantee the effectiveness of research if the unanimously adopted conventions are of a trivial nature and stand aside from the fundamental substantive problems. Consequently, the influence of consensus on the development of knowledge significantly depends on the nature of the methodology itself, conventionally chosen by the researchers.

In the humanities, many meanings and interpretations of the results of empirical research are usually offered, scientists tend to offer their own interpretation of observations each time. This suggests that one should always bear in mind the possible discrepancy between the adopted conventions and the consensus - in general, a fairly widespread occurrence of such a situation, which is not at all irrational or unproductive. Often in modern epistemology of science (K. Popper, P. Fayerabend, T. Kuhn, etc.), either the problem of explaining the high degree of agreement that is achieved in the science of the 20th century (40$50 \mathrm{~s})$, or the phenomenon of disagreements and bifurcations in science and their rational resolution (6070 s). Most likely, the high degree of agreement in the $40-50$ s is explained by the general global task of explaining the phenomenon of totalitarianism. The general object of research has generated a certain time period of the "model" consensus. Further social development gave rise to other models. But at the same time, it is obvious that there is a need for some unified theory explaining the emergence and mutual transition of consensus and dissensus in science. The solution to this dilemma is offered by the famous American sociologist Larry Laudan in his work Science and Values, who claims that in the humanities and social sciences, the differences are of the nature of an "epidemic", while in natural science, most scientists agree, at least on the fundamental components knowledge (even earlier T. Kuhn expressed a similar idea). Traditionally, it was believed that disagreement only arises if the evidence of fact is relatively weak and incomplete and it is enough to involve additional evidence or appropriate rules - and agreement will be reached. Laudan postulates that the problem should be considered at the "intersection between the works of philosophers and sociologists", since agreement, in particular when choosing a theory, develops not only in relation to the fact, but also in (first of all) the relation of methodological and axiological justification, which was written about neo-Kantians. In addition, it is necessary to take into account that the classical tendency to regard consensus as a condition of rationality, and dissensus as a condition of irrationality, is undermined by a number of factors actually acting in science. According to Laudan, there are four of them in general: scientific research is constantly in a situation of discussion, which is their inherent property; the relationship between theories can be defined by the "incommensurability thesis"; there are situations of "underdetermination" of theories by empirical data; finally, successful research activity in a "state of dissensus" is possible, and scientists who had high achievements most often violated the established norms. It follows from this that the consensus model, as a rule, is incomplete and does not correspond to the dynamics of real science; rather, dissensus is its attribute and marker. The dominant model of any scientific justification is hierarchical: at the lower level, the "factual" (factual consensus) is discussed, then generally accepted methodological rules as a means of achieving the goals of science (methodological consensus), and finally, the consensus of values and goals. The latter is either not recognized or not taken into account, since it has always been assumed that the values and goals of research are the same and equally understood by all. This model "postulates a unidirectional ladder of reasoning" from goals to factual statements, whereas in real science, reasoning goes in any conceivable field, linking goals, methods and results. Laudan is convincing in the assertion that there are no privileged levels, axiology, methodology and factual statements inevitably interact and intertwine. Consideration in the integrity of all three levels expresses the essence of the "network model" of scientific rationality, which makes it possible to understand the variety of their combinations that underlie consensus or dissensus. The network model expands the understanding of scientific rationality, not only linking it with a consensus on the goal, facts or methods, and even more so because there is a constant "shift in cognitive values", theories and methods change, accordingly, new conventions are applied, old ones are excluded, consensus and dissensus always 
exist, complementing each other and reflecting the general communicative nature of science. These ideas can become the basis for further study of the problem of conventionality as a consequence of communicative relations in scientific knowledge [2].

\section{References:}

1. Weber M. On some categories of understanding sociology // He. Fav. works. M, 1990.

2. Volnistaya M.G., Mamedov A.K. Scientific communications in the system of reproduction of knowledge // Scientific journal Higher School (Republic of Belarus). - 2018. - No. 3. - P. 43-48.

3. Kuhn T. The structure of scientific revolutions / Per. OF. Naletova. - M .: Progress, 1977.

4. Laudan L. Science and values // Modern philosophy of science: knowledge, rationality, values in the works of Western thinkers: a reader. M., 1996.

5. Mamedov A.K. Architecture of scientific knowledge (analysis of methodological foundations) // Sociology. - 2017. - No. 3. - P. 48-57.
6. Mamedov A.K. Logic of social knowledge (Popper vs Marx) // Sociology. - 2016. - No. 3. - P. 819.

7. Mamedov A.K. Epistemology of social knowledge. - CANON + Moscow, 2017.

8. Poser X. Rules as forms of thinking. About truth and conventions in sciences // Reason and Existence. Analysis of scientific and non-scientific forms of thinking. SPb., 1999.

9. Popper K. Logic and the growth of scientific knowledge: Fav. work. M., 1983.

10. Popper K. Open society and its enemies. Vol. 1. Enchantment of Plato. M., 1992. Poincaré A. About science. M., 1983.

11. Sapir E. Selected works on linguistics and cultural studies. M., 1993. Chudinov E.M. The nature of scientific truth. M., 1977.

12. Poisons V.A. Sociological research (methodology, program, methods). M., 1972. 